\title{
Penatalaksanaan kasus lesi endodontik-periodontik dengan keterlibatan furkasi pada gigi molar pertama rahang bawah kiri
}

\author{
Ellizabeth Yunita ${ }^{1 *}$, Diani Prisinda ${ }^{1}$
}

\author{
${ }^{1}$ Departemen Konservasi Gigi, Fakultas Kedokteran Gigi Universitas Padjadjaran, Indonesia \\ *Korespondensi: ellizabethvunitadra@amail.com \\ Submisi: 27 Juli 2018; Penerimaan: 28 November 2020; Publikasi online: 30 November 2020 \\ DOI: $10.24198 / j k g . v 32 i 1.18034$
}

\begin{abstract}
ABSTRAK
Pendahuluan: Lesi kombinasi endodontik dan periodontik umum ditemukan pada gigi dengan nekrosis pulpa. Hubungan simultan antara masalah pulpa dan penyakit periodontal dapat menyulitkan dalam menentukan diagnosis dan rencana perawatan. Tujuan laporan kasus ini adalah untuk memperlihatkan keberhasilan perawatan lesi endodontik periodontik disertai keterlibatan furkasi pada gigi molar pertama dengan penatalaksanaan kasus dari kerjasama dua bidang ilmu yang berbeda, ditunjukan dengan hilangnya lesi dan gejala yang terdapat di pasien. Laporan kasus: Gigi molar pertama rahang bawah kiri dengan diagnosis lesi endodontik primer disertai lesi periodontal sekunder (berdasarkan klasifikasi Simon) dirawat secara endodontik yang dikombinasikan dengan perawatan periodontal. Gigi 36 dirawat saluran akarnya terlebih dahulu dengan menempatkan medikasi antar kunjungan kemudian dilakukan restorasi akhir endocrown komposit. Perawatan dilanjutkan dengan pembedahan flap untuk mencapai akses ke area furkasi disertai penempatan bone graft pada defek furkasi. Kontrol dilakukan sampai 3 bulan setelah pembedahan periodontal dan memperlihatkan hasil yang baik. Simpulan: Perawatan lesi endodontik-periodontik pada pasien ini terlihat lesi menghilang, pemeriksaan subjektif dan objektif tidak memperlihatkan kelainan dan pasien merasa puas dengan perawatannya.
\end{abstract}

Kata kunci: Lesi endodontik-periodontik, defek furkasi, perawatan endodontik, kuretase furkasi, restorasi endocrown.

\section{Endodontic-periodontic lesion management with furcation involvement in the left mandibular first molar}

\begin{abstract}
Introduction: Combined endodontic and periodontic lesions are commonly found in teeth with pulp necrosis. The simultaneous association between pulp problems and periodontal disease can make it difficult to determine a diagnosis and treatment plan. This case report was aimed to demonstrate the successful treatment of endodontic-periodontic lesions with furcation involvement in the left mandibular first molar with collaborative management of two different disciplines, demonstrated by disappearance of the lesions and symptoms in the patient. Case report: Left mandibular first molar diagnosed with primary endodontic lesion and secondary periodontal lesion (according to Simon's classification) was treated endodontically in combination with periodontal treatment. The beginning of the treatment was initiated from the root canal of tooth 36, which was treated by administering the medication between visits, then the final composite endocrown restoration was performed. The treatment was then continued with flap surgery to achieve access to the furcation area with placement of a bone graft in the furcation defect. Control was carried out until three months after periodontal surgery and showed promising results. Conclusion: The treatment of endodontic-periodontic lesions in the patient showed that the lesions have disappeared. Subjective and objective examinations do not show any abnormalities, and the patient is satisfied with the treatment.
\end{abstract}

Keywords: Endodontic-periodontic lesion, furcation defect, endodontic treatment, furcation curretage, endocrown restoration. 


\section{PENDAHULUAN}

Hubungan antara penyakit pulpa dan periodontal pertama kali dikemukakan oleh Simring dan Goldberg. ${ }^{1}$ Istilah "Lesi endo-perio" sejak saat itu dipergunakan untuk menjelaskan produk inflamatori yang ditemukan di jaringan pulpa maupun periodontal dalam derajat keparahan yang variatif. ${ }^{1-8}$ Jaringan pulpa dan periodontal, dalam tahap perkembangan embriologi samasama berasal dari mesodermal. Sebagian "tooth bud (tunas gigi)" berkembang menjadi pulpa dan sebagian lagi menjadi jaringan periodontal. Perkembangan embrionik ini memberikan penjelasan mengenai hubungan anatomis antara dua struktur vital tersebut pada gigi. Tiga jalan masuk utama yang terlibat dalam perkembangan lesi endodontik periodontik diantaranya adalah tubulus dentin, saluran lateral dan aksesoris, serta foramen apikal. ${ }^{2-5}$

Keterlibatan furkasi merupakan kasus yang banyak terjadi dalam penyakit endodontik yang disertai dengan penyakit periodontal. Insidensi keterlibatan furkasi ini tinggi pada gigi molar pertama rahang atas dan bawah karena geligi tersebut merupakan gigi berakar ganda permanen yang pertama erupsi sehingga memiliki waktu paparan yang paling lama terhadap plak gigi. Furkasi vestibular merupakan bagian yang umum terpapar pada gigi molar rahang bawah. ${ }^{2,9}$

Lesi kombinasi endodontik dan periodontik pada umumnya banyak ditemukan pada gigi dengan nekrosis pulpa. Hubungan simultan antara masalah pulpa dan penyakit periodontal dapat menyulitkan untuk mendapatkan diagnosis yang akurat. Pengetahuan mengenai hal tersebut sangat diperlukan untuk menentukan diagnosis yang tepat karenasangatberpengaruhpadarencanaperawatan dan prognosis jangka panjang suatu kasus. ${ }^{2-12}$

Kerjasama antara bagian konservasi dan periodontik diperlukan untuk mencapai keberhasilan perawatan serta dapat memberikan perawatan endodontik, restoratif, dan periodontik yang adekuat. ${ }^{2-12}$ Prognosis dari lesi endodontik primer yang disertai keterlibatan periodontal sekunder biasanya bergantung pada tingkat keparahan keterlibatan jaringan periodontalnya. Perawatan endodontik yang adekuat harus didukung juga dengan perawatan periodontal yang efektif. $4,5,7,8,10$
Perawatan saluran akar perlu dilakukan baik untuk mencegah atau mengatasi penyakit periapikal. Lesi periapikal berkembang sebagai hasil interaksi antara bakteri dan produknya dengan pertahanan host, oleh karena itu resolusi penyembuhan penyakit tergantung pada pencegahan atau penghentian interaksi ini. Tantangannya tampaknya lebih besar lagi dengan adanya lesi periodontal karena dikaitkan dengan infeksi yang lebih luas. ${ }^{13}$ Perawatan saluran akar dilakukan terlebih dahulu, dengan demikian memberi waktu untuk penyembuhan jaringan periodontal. Observasi dan evaluasi dilakukan selama 2-3 bulan, kemudian dapat dilanjutkan dengan perawatan periodontal jika diperlukan. ${ }^{2,4-8,10}$

Tujuan laporan kasus ini adalah untuk memperlihatkan keberhasilan perawatan lesi endodontik periodontik disertai keterlibatan furkasi gigi molar pertama dengan penatalaksanaan kasus dari kerjasama dua bidang ilmu yang berbeda, ditunjukan dengan hilangnya lesi dan gejala yang terdapat di pasien.

\section{LAPORAN KASUS}

Seorang perempuan berusia 22 tahun datang ke Klinik PPDGS Konservasi Gigi RSGM Unpad dengan keluhan gigi belakang kiri bawah berlubang sejak kurang lebih 3 tahun yang lalu. Gigi pernah sakit berdenyut kira-kira 2 tahun yang lalu kemudian berobat ke dokter gigi setempat, diberi obat untuk mematikan syaraf serta tambalan sementara tetapi tidak kontrol lagi. Gigi sering sakit berdenyut sejak itu, bahkan sampai keluar nanah dari gusi di sebelah gigi tersebut, terakhir sekitar 3 bulan yang lalu. Gigi tidak sakit saat datang dan ingin dirawat. Pasien tidak memiliki riwayat penyakit sistemik dan tidak mengkonsumsi obat rutin. Hasil pemeriksaan fisik dan tanda vital dalam batas normal. Pemeriksaan ekstra oral menunjukkan wajah simetris, otot bibir normal, bibir tidak ada kelainan, TMJ kiri kliking, kelenjar limfe tidak teraba dan tidak sakit. Pemeriksaan intra oral menunjukan pasien memiliki karies pada beberapa gigi posterior rahang atas dan bawah.

Pemeriksaan klinis gigi 36 terdapat karies mencapai dentin yang dalam dengan kavitas di bagian oklusal (Gambar 1). Tes dingin, palpasi, dan tekan menunjukkan respon negatif sedangkan perkusi menunjukkan respon positif, tidak terdapat 
kegoyangan, serta jaringan sekitarnya terdapat resesi gingiva kurang lebih $1 \mathrm{~mm}$ di bagian bukal dengan kedalaman poket $5 \mathrm{~mm}$ di bagian mid bukalis mencapai furkasi.

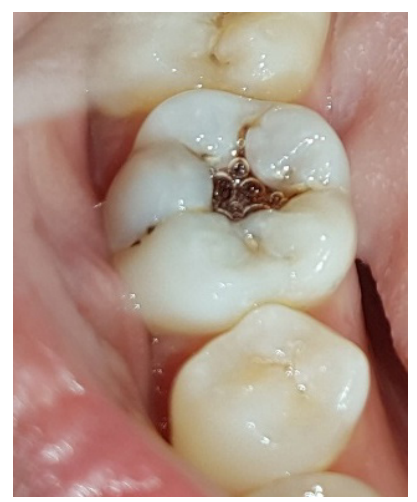

Gambar 1. Gambaran klinis gigi 36 sebelum dilakukan perawatan.

Pemeriksaan radiologi periapikal dilakukan sebagai penunjang dan memperlihatkan gambaran radiolusen dari email sampai pulpa di bagian oklusal mahkota gigi 36. Terdapat dua akar dengan 3 saluran akar (2 di mesial dan 1 di distal). Membran periodontalnya melebar di $1 / 3$ apikal kedua akar. Lamina dura juga memperlihatkan gambaran terputus di 1/3 apikal kedua akar. Pada daerah furkasi terdapat gambaran radiolusen dengan kedalaman lebih kurang $4 \mathrm{~mm}$ ke apikal dari furkasi serta meliputi apikal akar mesial dan distal dengan diameter sekitar $2 \mathrm{~mm}$ (Gambar 2A).

Diagnosis dari kasus tersebut adalah nekrosis pulpa gigi 36 disertai periodontitis apikalis asimptomatik (AAE, 2013) dengan klasifikasi lesi endodontik primer disertai keterlibatan periodontal sekunder (Klasifikasi Simon). Rencana perawatan tahap pertama meliputi scaling, root planning serta Dental Health Education (DHE) dan dilakukan kontrol 1 minggu. Tahapan kedua dilakukan perawatan endodontik pada gigi 36 dengan restorasi definitif endocrown komposit. Perawatan kemudian dilanjutkan dengan pembedahan flap untuk membersihkan area furkasi dan penempatan bone graft serta dilakukan kontrol 1 minggu, 1 bulan, dan 3 bulan setelah pembedahan. Prognosis kasus ini baik, karena posisi gigi tidak menyulitkan untuk dilakukan perawatan, pasien kooperatif dan berespon baik pada DHE, usia masih muda, serta tidak ada kelainan sistemik.

Pasien diberikan informasi mengenai keadaan giginya dan seluruh tahapan perawatan yang akan dilakukan serta komplikasi yang mungkin terjadi. Pasien diminta untuk menandatangani lembar informed consent setelah mengerti dan setuju.

Perawatan endodontik dimulai dengan pemasangan rubber dam, kemudian pembukaan akses koronal menggunakan bur Endo-Access dan Endo-Z (Dentsply ${ }^{\circledR}$ ) sampai menembus kamar pulpa. Negosiasi saluran akar dan patensi apikal dilakukan menggunakan K-File nomor 8 dan 10 (M-Access, Dentsply ${ }^{\circledR}$ ), kemudian dilakukan irigasi menggunakan $\mathrm{NaOCl} 5.25 \%$ setiap pergantian file. Pengukuran panjang kerja dilakukan menggunakan apex locator (Morita) dilanjutkan dengan penentuan glide path menggunakan Rotary Proglider nomor 17/.02 (Dentsply®).

Cleaning dan shaping dilakukan pada ketiga saluran akar menggunakan TF Adaptive System (Sybron Endo). Master apical file pada ketiga saluran akar adalah file TF ML3 (Sybron Endo). Irigasi dilakukan menggunakan $\mathrm{NaOCl} 5.25 \%$, EDTA 17\%, serta Klorheksidin 2\% dengan bilasan aquabidest di setiap pergantian cairan irigasi. Cairan yang ada di saluran akar saat irigasi diagitasi menggunakan Endo Activator (Dentsply®). Saluran akar kemudian dikeringkan menggunakan paper point dan dilakukan pemberian medikasi intrakanal kalsium hidroksida (Calcipex $\left.{ }^{\circledR}\right)$ serta ditutup tambalan sementara.

Kunjungan berikutnya dilakukan konfirmasi master cone gutta-percha dengan Pemeriksaan radiologi (Gambar 2B). Saluran akar kemudian diobturasi menggunakan TF ML3 gutta-percha points (Sybron Endo) dan sealer $\mathrm{AH}$ Plus (Dentsply $\AA$ ) dengan teknik kondensasi lateral. Gutta-percha dipotong sampai batas orifis, kavitas dibersihkan dari sisa sealer, kemudian ditutup dengan low shrinkage flowable composite (SDR, Dentsply) dan ditutup tambalan sementara. Pemeriksaan radiologi dilakukan dan didapatkan hasil obturasi yang hermetis pada ketiga saluran akar (Gambar 2C®).

Kontrol paska obturasi memperlihatkan gigi 36 asimptomatik. Meskipun tidak ada respon pada tes perkusi dan tekan serta tidak terdapat kegoyangan, tetapi gingiva di bagian bukal masih resesi dan poket masih dalam $(5 \mathrm{~mm})$. Pemeriksaan radiologi kontrol post obturasi menunjukkan lesi periapikal dan furkasi menunjukkan perbaikan dibandingkan dengan kondisi awal (Gambar 2D). Gigi 36 kemudian direstorasi dengan endocrown 


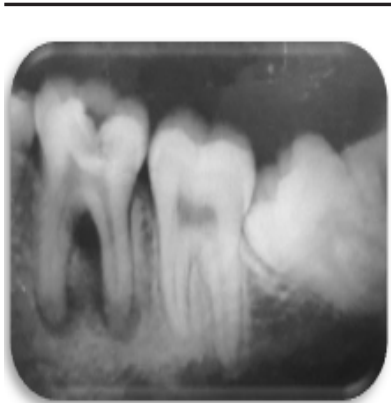

A

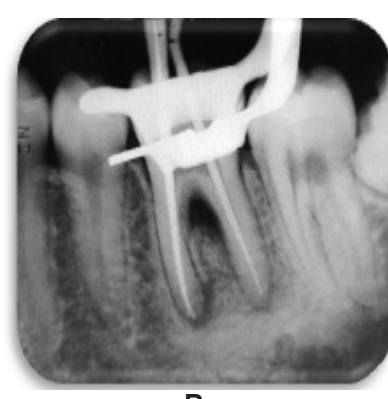

B

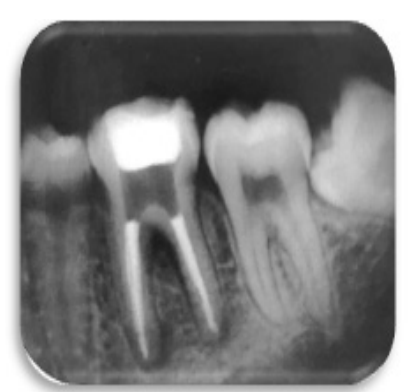

C

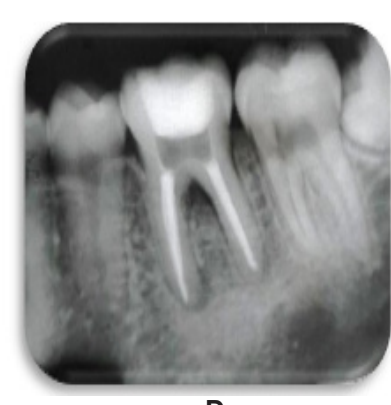

D

Gambar 2 A. Gambaran radiografi gigi 36 sebelum dilakukan perawatan; B. Trial obturasi; C. Obturasi; D. Kontrol 2 minggu paska obturasi saluran akar gigi 36 .

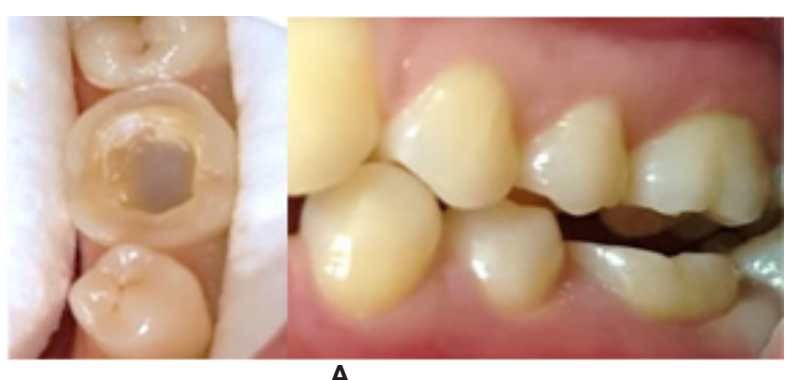

A

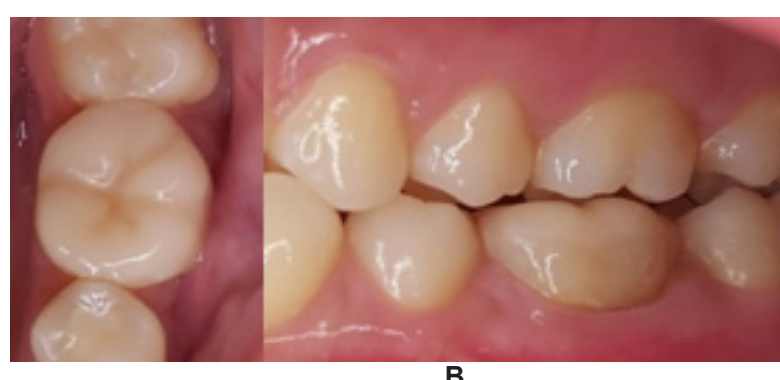

B

Gambar 3 A-B. Preparasi endocrown gigi 36; C-D. Paska sementasi endocrown komposit gigi 36.

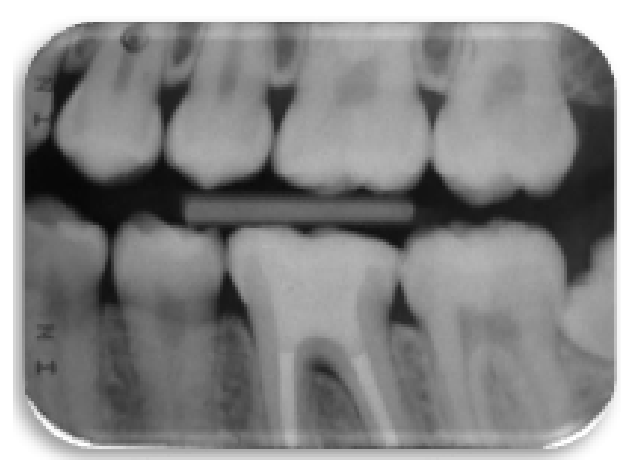

Gambar 4. Radiografi bitewing setelah sementasi endocrown komposit gigi 36 . komposit (Gambar 3). Pemeriksaan kontrol radiografi bitewing dilakukan untuk memastikan restorasi telah menutup sempurna dan tidak ada overhang pada permukaan proksimal gigi 36 (Gambar 4).

Kontrol 1 minggu dilakukan paska sementasi endocrown komposit gigi 36 dilakukan. Pemeriksaan menunjukkan gigi tersebut tidak ada keluhan, tes perkusi memberikan hasil negatif dan jaringan sekitar dalam keadaan normal (gingiva tidak oedem) walaupun masih ada poket dalam
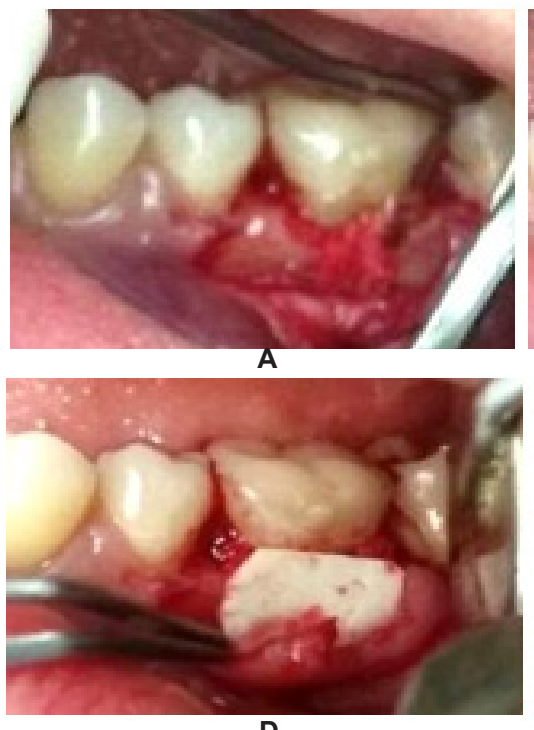

D

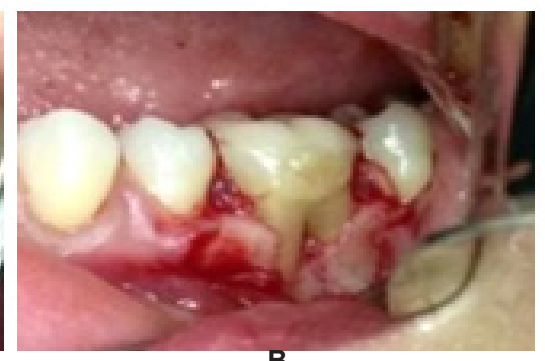

B

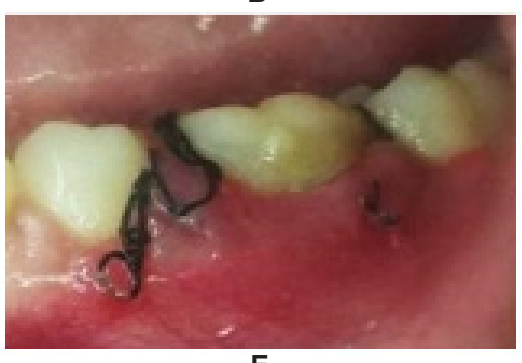

E
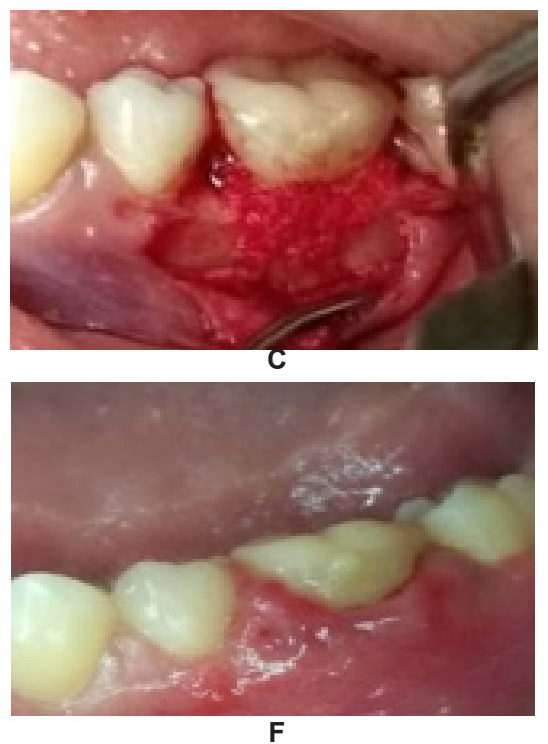

$\mathbf{F}$

Gambar 5. Tahapan pembedahan kuretase furkasi gigi 36: A. Jaringan granulasi di furkasi terlihat setelah flap dibuka;

B. Permukaan akar setelah dilakukan kuretase, scaling dan root planning; C. Penempatan bone graft; D. Peletakkan membrane perikardium; E. Penjahitan flap; F. Kontrol 1 minggu paska pembedahan gigi 36. 
sebanyak $4 \mathrm{~mm}$ di bagian mid bukalis, oleh karena itu pasien dijadwalkan untuk tindakan pembedahan periodontal (kuretase furkasi) seminggu kemudian di Klinik PPDGS Periodonsia RSGM Unpad (Gambar 5). Pasien diberikan informasi mengenai prosedur yang akan dilakukan dan diminta untuk menandatangani lembar informed consent setelah mengerti dan menyetujui setiap tahap prosedurnya.

Pasien diminta datang untuk kontrol 1 minggu, 1 bulan, dan 3 bulan paska operasi pembedahan periodontal. Pemeriksaan klinis pada kontrol 3 bulan memperlihatkan gingiva dalam batas normal dan dari pengukuran kedalaman sulkus gingiva melalui probing di medial permukaan bukal gigi 36 didapatkan 3 mm (Gambar 6).

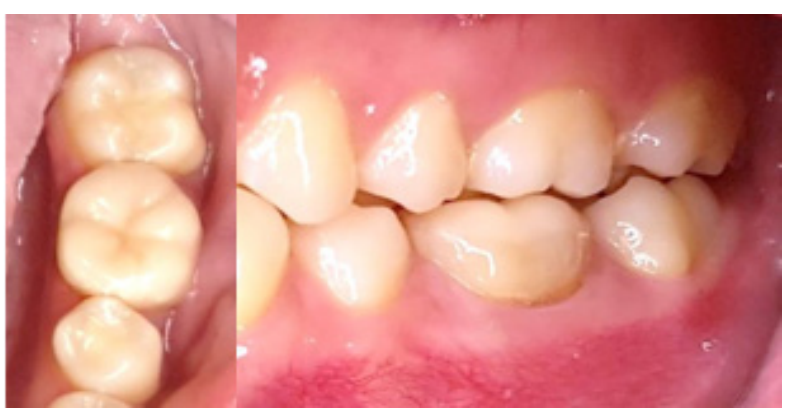

Gambar 6. Gambaran klinis kontrol 3 bulan paska perawatan gigi 36 .

Pemeriksaan radiologi periapikal dilakukan untuk mengevaluasi perkembangan keadaan gigi 36 setelah perawatan endodontik dan periodontik selesai.

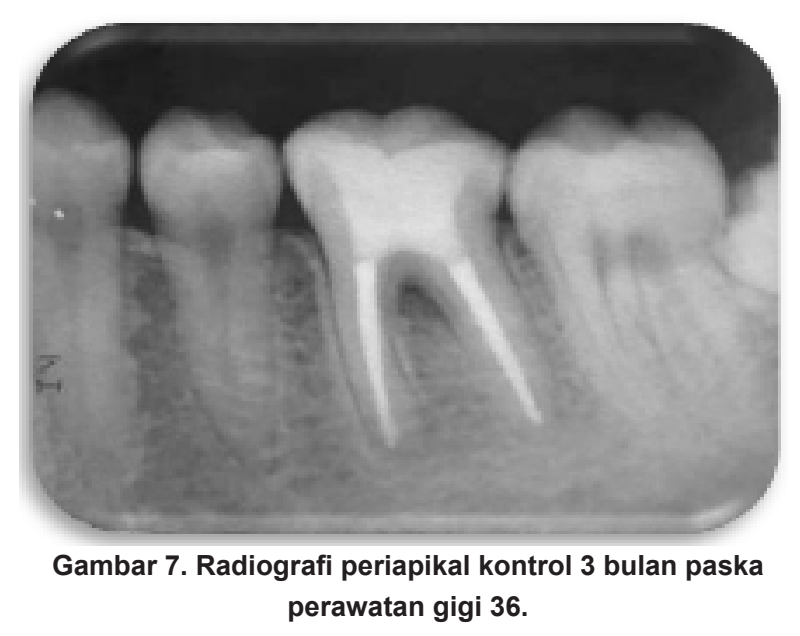

Hasil evaluasi setelah dilakukan perawatan lesi endodontik-periodontik pada pasien ini terlihat lesi menghilang (Gambar 7), pemeriksaan subjektif dan objektif tidak memperlihatkan kelainan dan pasien merasa puas dengan perawatannya. Pasien sudah diminta persetujuan untuk mempublikasikan kasus ini demi kepentingan pendidikan. Laporan kasus ini telah mendapatkan persetujuan dari pasien melalui informed consent yang diberikan

\section{PEMBAHASAN}

Penentuan diagnosis pada gigi yang memiliki lesi endodontik dan periodontal merupakan suatu hal yang tidak mudah. Diagnosis yang tepat berhubungan erat dengan penentuan rencana perawatan serta prognosis jangka panjang suatu kasus. ${ }^{1-12} \mathrm{Hal}$ ini menegaskan bahwa kita perlu mengetahui klasifikasi lesi endodontik periodontal. Klasifikasi yang sering digunakan yaitu Klasifikasi Simon et al. (1972) yang membagi 5 klasifikasi lesi endodontik periodontal berdasarkan etiologi, diagnosa, perawatan, dan prognosisnya. Klasifikasi tersebut terdiri dari lesi endodontik primer, lesi periodontal primer, lesi endodontik primer disertai keterlibatan periodontal sekunder, lesi periodontal primer disertai keterlibatan endodontik sekunder, serta lesi kombinasi endodontik-periodontal. 2-5,7,8,10,11,12,14

Kasus yang diuraikan diatas termasuk kedalam klasifikasi lesi endodontik primer disertai keterlibatan periodontal sekunder. Lesi seperti ini memerlukan perawatan saluran akar maupun perawatan periodontal regeneratif. Rencana perawatannya pertama-tama difokuskan untuk menghilangkan infeksi dari sistem saluran akar dan kemudian diobservasi. Perawatan endodontik walaupun dilakukan secara efektif seringkali tidak cukup untuk memperbaiki kehilangan jaringan tulang yang parah akibat periodontitis. Tujuan dari tindakan bedah periodontal yang dilakukan adalah untuk membersihkan seluruh jaringan nekrotik dan memberikan dukungan bagi regenerasi jaringan keras dan lunak dengan perlekatan yang baru. 2,4,5,6,7,8,10,12,13 Preparasi saluran akar pada kasus ini menggunakan sistem TF Adaptive (Sybron Endo) yang gerakannya rotasi kontinu dan resiprokasi dengan teknik crown down. Ketika jumlah tekanan pada file minimal, file bergerak secara rotasi. File akan bergerak secara interrupted continous rotation yang membuat cutting lebih efisien jika file terjebak pada dentin dan diberikan tekanan. Ketika negosiasi saluran akar dan tekanan instrumen meningkat, gerakan file berubah menjadi resiprocal, dengan arah searah jarum jam dan 
berlawanan arah jarum jam. Gerakan adaptif dan pola file yang berpilin meningkatkan fleksibilitas instrumen dan memungkinkan file menyesuaikan gaya torsional intrakanal sesuai dengan jumlah tekanan beban pada file tersebut. Hal ini juga dapat menurunkan resiko kegagalan preparasi saluran akar karena gerakan terbaik dalam konsisi klinis yang berbeda dipilih secara otomatis oleh motor adaptifnya. ${ }^{15,16}$

Irigasi memiliki peran sentral dalam perawatan endodontik. Irigasi memfasilitasi pembersihan mikroorganisme, sisa-sisa jaringan dan chip dentin dari saluran akar melalui mekanisme flushing selama dan setelah instrumentasi. Irigasi juga dapat membantu mencegah pemadatan dari jaringan keras dan lunak di saluran akar apikal dan ekstrusi material terinfeksi ke daerah periapikal. ${ }^{17,18,19}$ Bahan irigasi saluran akar yang digunakan adalah $\mathrm{NaOCI} 5.25 \%$, $\mathrm{CHX} 2 \%$, dan EDTA $17 \%$ dengan aquabidest steril sebagai bilasan diantara pergantian irigan. Tidak ada cairan irigasi tunggal yang cukup efisien dalam mencakup semua fungsi yang diperlukan dari irigasi tersebut. Irigasi yang optimal didasarkan pada penggunaan gabungan dari 2 atau beberapa cairan irigasi, dalam urutan tertentu, untuk menentukan dapatnya tujuan yang aman dan efektif dalam melakukan irigasi. $17,18,19,20$

Medikamen intrakanal antar kunjungan kalsium hidroksida yang bersifat bakterisidal, antiinflamasi, dan proteolitik digunakan agar dapat menghambat resorpsi dan merangsang perbaikan jaringan periapikal. Penggunaan medikamen ini biasanya dapat memperbaiki lesi dalam waktu beberapa minggu. . $^{2,4,5,6,7}$ pada kasus ini menggunakan medikamen intrakanal kalsium hidroksida selama 4 bulan sampai menunjukkan adanya perbaikan lesi periapikal pada kasus ini kemudian dilakukan obturasi saluran akar.

Tahap akhir dari perawatan endodontik adalah obturasi tiga dimensi dari sistem saluran akar. Obturasi yang hermetis mengharuskan bahan pengisi menutup rapat ke arah apikal maupun ke lateral saluran akar sehingga mikroorganisme atau cairan dari jaringan tidak masuk ke dalam ruang yang masih kosong di dalam saluran akar tersebut. ${ }^{21,22}$ Bahan pengisi yang umum dipakai adalah gutta-percha, tetapi bahan ini tidak dapat menutup saluran akar secara hermetis tanpa adanya sealer. Sealer dibutuhkan untuk melekatkan, mengisi bentuk irregular dan diskrepansi minor antara bahan pengisi inti (gutta-percha) dan dinding saluran akar. Sealer juga berfungsi sebagai lubrikan saat prosedur obturasi dan mengisi saluran akar aksesoris. Penggunaan sealer berbahan dasar semen resin dapat mengurangi kebocoran mikro sehingga berkontribusi terhadap keberhasilan perawatan saluran akar. ${ }^{23,24}$

Regenerasi jaringan keras dilakukan menggunakan bonegraft pada daerah furkasi setelah perawatan endodontik selesai. Bone graft yang digunakan yaitu karbonat apatit Gama$\mathrm{CHA}$ yang merupakan suatu material pengganti tulang yang diproduksi secara biomimetis dan identik dengan tulang asli manusia. Gama-CHA mengandung karbonat apatit serta polimer berupa kolagen terdenaturalisasi yang berfungsi untuk mempercepat proses regenerasi jaringan tulang, memiliki sifat osteokonduksi, osteoinduksi, dan osteogenesis. ${ }^{25,26}$ Pada kontrol 3 bulan, dalam Pemeriksaan radiologi telah terlihat adanya pertumbuhan tulang yang signifikan di daerah furkasi tersebut.

Restorasi akhir pada kasus ini adalah endocrown komposit. Gigi yang telah dirawat endodontik lebih rentan terhadap fraktur. Salah satu penyebabnya adalah hilangnya substansi gigi seiring dengan proses patologis dan jalannya perawatan endodontik. Perubahan biomekanis ini memberikan dampak negatif pada prognosis jangka panjang gigi tersebut. Pertimbangan mengenai restorasi akhir gigi yang telah non vital diantaranya adalah pemilihan material yang dipakai harus mampu untuk menggantikan struktur gigi yang hilang agar fungsional, serta memiliki sifat mekanis, estetik, dan penutupan mahkota yang adekuat. ${ }^{27,28}$

Keuntungan utama dari restorasi adhesif endocrown adalah karena tidak memerlukan bentuk retensi yang besar jika permukaan yang tersedia cukup, sehingga tidak memerlukan penggunaan pasak. Tujuan dari penggunaan pasak adalah untuk menstabilisasi struktur mahkota gigi yang tersisa dan menggantikan jaringan mahkota yang hilang. Beberapa penelitian membuktikan bahwa pasak dapat memperkuat gigi di bagian servikal dengan adanya kohesif total antar permukaan, tetapi sebagian besar penelitian menyatakan bahwa pasak tidak memiliki efek penguat. Pasak 
metal terbukti tidak memperkuat gigi tetapi lebih berkontribusi pada melemahnya struktur gigi. Penelitian in vitro lainnya memperlihatkan tidak adanya perbedaan dari segi retensi, adaptasi marginal, dan resistensi terhadap fraktur antara gigi vital dengan gigi non vital yang direstorasi dengan onlay yang didukung pasak fiber. ${ }^{27,28}$ Preparasi minimal invasif dengan mempertahankan jaringan secara maksimal dan konservatif merupakan gold standard untuk merestorasi gigi paska perawatan endodontik. Berdasarkan penelitian pada saat simulasi pengunyahan, gigi molar yang direstorasi dengan endocrown memiliki tingkat kegagalan lebih rendah jika dibandingkan dengan pasak fiber reinforced dan crown. ${ }^{28}$

\section{SIMPULAN}

Perawatan lesi endodontik-periodontik pada pasien ini terlihat lesi menghilang, pemeriksaan subjektif dan objektif tidak memperlihatkan kelainan dan pasien merasa puas dengan perawatannya.

\section{DAFTAR PUSTAKA}

1. Medika CA, Sitam S, Epsilawati L. Analisis lesi endo-perio di periapikal melalui radiografi. J. Rad Dentomak Ind. 2019;3(2): 27-30. DOI: 10.32793/jrdi.v3i2.491

2. NanavatiB,BhavsarNV, MaliJ.Endo periodontal lesion - A case report. J Adv Oral Res. 2013; 4(1): 23-27. DOI: 10.1177/2229411220130104

3. Joshi $M$, Kosala M, Sharma D, Prasanth $T$. Management of Endo-Perio Lesion: A Case Report. Int J Sci Res Pub. 2020; 10 (1): 603614. DOI: 10.29322/IJSRP.10.01.2020.p9792

4. Khan RN, Kumar A, Chadgal S, Jan SM. Endo-Perio Interrelationship - An Overview. International J Inform Res Rev. 2017; 4(3): 3895-3898. DOI: 10.9790/0853-1712091521

5. Parolia A, Gait TC, Porto IC, Mala K. Endoperio lesion: A dilemma from $19^{\text {th }}$ until $21^{\text {st }}$ century. J Interdiscip Dent. 2013; 3(1): 2-11. DOI: 10.4103/2229-5194.120514

6. Alfawaz Y. Management of an Endodonticperiodontal Lesion caused by latrogenic Restoration. World Journal of Dentistry. May-June 2017; 8 (3): 1-8. DOI:10.5005/JP_ JOURNALS-10015-1444

7. Saha AP, Chakraborty A, Saha S. Endodontic- periodontal lesion: A two way traffic. International J Appl Dent Sci. 2018; 4(4): 223228.

8. Peeran SW, Thiruneervannan M, Abdalla KA, Mugrabi MH. Endo-Perio Lesions. International Journal of Scientific \& Technology Research. May 2013; 2(5): 268-274.

9. Marcaccini A, \ Pavanelo A, Nogueira AVB, Souza JACMorphometric study of the root anatomy in furcation area of mandibular first molars. J. Appl. Oral Sci. 2012; 20(1): 76-81. DOI: 10.1590/S1678-77572012000100014.

10. Suchetha A, Khawar S, Sapna N, Apoorva SM, Darshan BM, Bhat D. Endo-perio lesion: A case report. Inte J Appl Dent Sci. 2017; 3(3): 113-116.

11. Al-Fouzan KS. A new classification of endodontic-periodontal lesions. Int J Dent. 2014;2014:919173. DOI: 10.1155/2014/919173. Epub 2014 Apr 14.

12. Bonaccorso A, Tripi TR. Endo-perio lesion: Diagnosis, prognosis and decision-making. Endodontic Practice Today. 2014;8(2):105-127

13. Hargreaves KM, Berman LH. Cohen's pathways of the pulp. $11^{\text {th }}$ ed. Missouri: Elsevier. 2016 p. 120

14. 14. Simon JHS, Glick DH, Frank AL. The Relationship of Endodontic-Periodontic Lesions. 2013; 39(5); 41-6. DOI: 10.1016/i. joen.2013.02.006

15. Keskin B, Özyürek T, Furuncuoğlu F, Inan $U$. The Effects of Adaptive Motion on Cyclic Fatigue Resistance of Twisted Files. J Dent App. 2016; 3(3): 337-339.

16. Tocci L, Plotino G, Al-Sudani D, Rubini AG, Sannino G, Piasecki L, Putortì E, Testarelli L, Gambarini G. Cutting efficiency of instruments with different movements: a comparative study. J Oral Maxillofac Res. 2015; 30;6(1):e6. DOI: 10.5037/jomr.2014.6106.

17. Asgary S, Nosrat A, Seifi A. Management of inflammatory external root resorption by using calcium-enriched mixture cement: A case report. J Endo 2011; 37(3): 411-3. DOI: 10.1016/j.joen.2010.11.015

18. Haapasalo M, Shen Y, Qian W, Gao Y. Irrigation in endodontics. Dent Clin North Am. 2010; 54(2): 291-312. DOI: 10.1016/j.cden.2009.12.001.

19. Beus C, Safavi K, Stratton J, Kaufman B. Comparison of the effect of two endodontic 
irrigation protocols on the elimination of bacteria from root canal system: a prospective, randomized clinical trial. J Endod. 2012 Nov;38(11):1479-83. DOI: 10.1016/j. joen.2012.07.005.

20. Srikanth $P$, Krishna AG, Srinivas $S$, et al. Minimal Apical Enlargement for Penetration of Irrigants to the Apical Third of Root Canal System: A Scanning Electron Microscope Study. J Int Oral Heal : JIOH. 2015; 7(6): 92-96.

21. Wijaya $\mathrm{Y}$, Natasasmita $S$, SukartiniThe difference of $17 \%$ ethylenediaminetetraacetic acid irrigation material contact time of 60 seconds and 30 seconds toward of cleanliness of apical third root canal wall. 2011;23(3):14954. DOI : 10.24198/pjd.vol23no3.14030 22.

22. Long CD, He J, Woodmansey KF. The effect of obturation technique on the push-out bond strength of calcium silicate sealers. DOI: 10.1016/j.joen.2014.11.002

23. Kumar RV, Shruthi C. Evaluation of the sealing ability of resin cement used as a root canal sealer: An in vitro study. J Conserv Dent. 2012; 15(3): 274-7. DOI: $10.4103 / 0972-0707.97958$
24. Boţa G, Cristian A. Study Regarding Root Canal Sealants by Using Four Different Materials for Endodontic Treatment. Acta Medica Transilvanica. 2015; 20 (4):139-141.

25. Surbakti A, Oley MC, Prasetyo E. Perbandingan antara penggunaan karbonat apatit dan hidroksi apatit pada proses penutupan defek kalvaria dengan menggunakan plasma kaya trombosit. Jurnal Biomedik (JBM). Juli 2017; 9 (2): 107-114. DOI: https://doi.org/10.35790/ ibm.9.2.2017.16359

26. Saskianti T, Ramadhani R, Budipramana ES, Pradopo S , Suardita K. Potential Proliferation of Stem Cell from Human Exfoliated Deciduous Teeth (SHED) in Carbonate Apatite and Hydroxyapatite Scaffold. J Int Dent Med Res. 2017; 10 (2): 350-353.

27. Rocca GT, Krejci I. Crown and post-free adhesive restorations for endodontically treated posterior teeth: from direct composite to endocrowns. Eur J Esthet Dent. 2013; 8(2): 156-79.

28. Sevimli G, Cengiz S, Oruc MS. Endocrowns: review. J Istanb Univ Fac Dent. 2015 Apr 29;49(2):57-63. DOI: 10.17096/jiufd.71363. 